\title{
The Death of Isabella Della Volpe: Four Eyewitness Accounts of a Postmortem Caesarean Section in 1545
}

\section{Citation}

Park, Katherine. 2008. The death of Isabella Della Volpe: Four eyewitness accounts of a postmortem caesarean section in 1545. Bulletin of the History of Medicine 82(1): 169-187.

\section{Published Version}

http://www.press.jhu.edu/journals/bulletin_of_the_history_of_medicine/

\section{Permanent link}

http://nrs.harvard.edu/urn-3:HUL.InstRepos:3221078

\section{Terms of Use}

This article was downloaded from Harvard University's DASH repository, and is made available under the terms and conditions applicable to Open Access Policy Articles, as set forth at http:// nrs.harvard.edu/urn-3:HUL.InstRepos:dash.current.terms-of-use\#OAP

\section{Share Your Story}

The Harvard community has made this article openly available. Please share how this access benefits you. Submit a story.

Accessibility 
"The Death of Isabella Della Volpe: Four Eyewitness Accounts of a Postmortem Caesarean Section in 1545," The Bulletin of the History of Medicine 82 (2008): 169-87.

Texts and Documents

The Death of Isabella Della Volpe: Four Eyewitness Accounts of a Postmortem Caesarean Section in 1545

$<$ sc $>$ Katharine Park $<$ end sc $>$

Summary: This article provides a transcription and translation of four notarized declarations describing the events surrounding a post-mortem caesarean section performed in 1545 in Vercelli, a small city in the Duchy of Savoy. After her death in the late stages of pregnancy, Isabella della Volpe's body was opened and her fetus excised by a local barber, aided by a surgeon and a midwife. The article argues that the post-mortem caesarean section was a well known and widely accepted procedure and that it might be motivated by financial and legal as well as religious concerns; not only was it important to baptize the child for its salvation, but the fate of the mother's dowry, as in this case, might depend on whether she died with or without living issue.

Keywords: caesarean section, childbirth, baptism, dowry, medicine and the law, Vercelli 
The document transcribed and translated in the appendix consists of the sworn declarations of three men and one woman: a surgeon, a priest, a barber, and a maidservant. Each describes the circumstances surrounding the death in 1545 of Isabella della Volpe, who came from a prominent family in Vercelli, a small city of about 8,500 inhabitants in the Duchy of Savoy. ${ }^{1} \mathrm{~A}$ year earlier, Isabella had married an eminent local physician, Marcantonio de Cusano, and had soon become pregnant $<\mathrm{em}>$ but before she had a chance to deliver, she fell mortally ill and died. Her corpse was opened in order to extract and baptize her fetus, christened Camilla, who also died shortly thereafter, according to the witnesses. The surgical procedure was a familiar one, as the document makes clear. What distinguishes this case from most others of its sort is the legal actions it engendered, of which these four declarations are the only record that has yet come to light.

Even in the absence of additional documentation, the legal issues at stake are clear. They did not involve medical malpractice, or the violation of any kind of prohibition: the church strongly supported the practice of fetal excision, and everyone involved seems to have accepted the need for the operation and to have been satisfied with the actions of the surgeon and the barber. Rather, as implied by the form and content of the four declarations $<$ em $>$ made "on behalf of" Isabella's husband, Marcantonio, and "requested and given to" her paternal uncle Nicola della Volpe $<$ em $>$ the case reflected a conflict between Isabella's husband and her natal family regarding property belonging to the latter: her dowry of 1,200 gold scudi (a very large sum), augmented by the 800 scudi she had inherited from her father Agostino on his death in 1542, together with any additional wealth that might have been given to her by other family members. ${ }^{2}$ The witnesses' declarations appear to have been collected in order to fight, or to head off, a 
lawsuit on the part of Isabella's uncle, who might reasonably have sued her husband to recover this considerable property, the legal fate of which hinged on the status of Isabella's daughter, delivered by a surgical procedure after her mother's death: if it were determined that Isabella had indeed borne a living child, Marcantonio would have been able to claim Isabella's property through their joint issue; otherwise, it would have reverted to Isabella's paternal uncle Nicola. ${ }^{3}$ Thus, as key passages in the declarations indicate, the case turned on two main questions: 1) whether the child was delivered alive, and 2) whether it was close enough to term (i.e., well enough developed physically) to qualify as a legal heir. In addition to these financial considerations (which appear in other legal cases beginning in the fourteenth century), however, the story of Isabella's death illuminates the role of men and women in childbirth practices, as well as contemporary attitudes toward the caesarean operation. ${ }^{4}$

Unlike the detailed eyewitness accounts of two other births in fifteenth-century Marseille and Zaragoza that have appeared, or are shortly to appear, in English translation, ${ }^{5}$ this document, strictly speaking, describes a deathbed rather than a childbirth scene. Isabella never went into labor, but died from an illness that the attending surgeon, Battista de Crollis of Cossato, described in his declaration as an "obstruction [opulatione] of the brain," which had deprived her of "the power of speech three or four days before her death"<em $>$ perhaps the condition that we know as eclampsia. The midwife was called only after Isabella had died, once the women present at her deathbed had determined by touch that her fetus was still alive $<\mathrm{em}>$ or so they claimed $<$ em $>$ and had asked Battista, who happened to be visiting, to cut open her uterus to extract it.

This surgical procedure was obviously familiar to both the surgeon and the women at 
whose request it was performed. ${ }^{6}$ It had long been associated with the birth of Gaius Julius Caesar (popularly conflated with his descendant Julius Caesar), as described in the Natural History of the Roman writer Pliny the Elder; this apocryphal story of Caesar's birth was disseminated in numerous late medieval and Renaissance texts and images (e.g., Fig. 1) and eventually gave the operation its modern name. ${ }^{7}$

\section{$<$ FIG 1 here $>$}

Unlike the modern "caesarean" section, however, the premodern version of the procedure was never $<$ em $>$ at least in theory $<$ em $>$ performed on living women: contemporary obstetrical practice subordinated the interests of the child to thoseof the mother, who could not have been expected to survive the operation. ${ }^{8}$ Nor was it performed with any frequency before the late thirteenth or early fourteenth century, when it began rapidly to gain currency in response to a series of ecclesiastical decrees promoting it. The principal goal of the operation, which was also invoked by the witnesses in Isabella's case, was to baptize the infant and thereby save its soul from eternal damnation; in addition, the procedure eliminated any obstacle to the burial of the mother in consecrated ground, since, at least in some parts of northern Europe, the belief persisted that this was permissible only if her unbaptized (and therefore un-Christian) fetus were previously excised. ${ }^{9}$

In the early fourteenth century, instructions for the procedure began to appear in medical and surgical texts. ${ }^{10}$ The most influential of these was the Great Surgery (Chirurgia magna) of the French surgeon Guy de Chauliac, written in 1363. After describing how to extract a dead 
fetus from a living woman, Guy turned to the contrary case:

$<\mathrm{ext}>$

If it happens that the woman herself is dead, ... and you suspect that the fetus is alive, since the Lex Regia [an early Roman law] forbids for a pregnant woman to be buried with the fetus still inside her, the woman's mouth and uterus are held open (as women wish), and the woman should be opened with a razor by making a lengthwise cut in the left side, since that part is freer than the right on account of the liver, and the fetus should be extracted using the fingers. Julius Caesar was extracted in this way, as is recounted in The Deeds of the Romans. ${ }^{11}$

The practice of holding open the mother's mouth and/or uterus was intended to keep the fetus from suffocating before its extraction $<\mathrm{em}>$ although Guy, who was well versed in Galenic anatomy, seems here to express skepticism about its utility, presenting it as a concession to women in the birthing room, rather than as a medical necessity.

In the second half of the fifteenth century, accounts of the operation appeared in private letters and Italian household records. One of the earliest such references dates from 1462, when Gasparo Nadi, a master mason from Bologna, described the death of his wife Catalina in his diary: "since she could not give birth, Master Giovanni of Navarre, the doctor, extracted [the child] from her body; it was a boy, and it pleased God that it was fated that he die after a little more than an hour. I did this because it was impossible for me to save her, since I loved her enormously." ${ }^{12}$ Other women delivered in this way included Francesca Pitti, wife of the eminent 
Florentine banker Giovanni di Francesco Tornabuoni; he described the experience in a poignant letter to Lorenzo de' Medici in $1477 .{ }^{13}$ By the early sixteenth century, many of the discussions of the practice in the works of Italian surgical writers imply experience with the procedure. Pietro d'Argellata, professor of medicine at the university of Bologna, took most of his account of the operation from Guy de Chauliac. While Guy recommended making the incision on the left side of the mother's body, Pietro noted that he had tried other approaches: "I have sometimes made the incision from the breastbone to the pubic bone, carefully, so as not to touch the intestines or the child. And in this way I have extracted the child. But in truth, the first method pleases me more." 14

Although some early medical texts describe the procedure as being performed by midwives, ${ }^{15}$ all of the Italian texts and images of which I am aware, beginning in the early fourteenth century, portray it as being done by a medical man, usually a barber or a surgeon, with a midwife in attendance; in Fig. 1, for example, an early sixteenth-century Venetian woodcut of the birth of Caesar, a surgeon does the cutting, while a midwife receives the child. The prominence of male practitioners in Italian accounts of fetal excision reflects the early involvement of Italian physicians, surgeons, and barbers in obstetrics and gynecology. At least in Italy, this did not represent a "usurpation" of the traditional functions of midwives by doctors, as is sometimes argued; there is little evidence to suggest that midwives had constituted a welldefined occupational group much before the late thirteenth century, or that they provided any care beyond the actual delivery of babies. ${ }^{16}$ Instead, we find a clear division of labor between doctors and midwives in Italian cities: midwives delivered babies; physicians provided pre- and postpartum medical care; and surgeons and barbers, as in the case of Isabella della Volpe, 
performed operations such as fetal excisions and embryotomies. ${ }^{17}$

The procedure performed on Isabella in 1545 reflected this division of labor: when the women attending her saw that she had died, they turned for help to the surgeon Battista de Crollis, a family friend who had been attending her in her last illness and who happened to be in the house at the time. Unwilling to open Isabella's corpse, he told them to call a barber, Stefano de Fango, who arrived soon afterward with a midwife, Elena; the two of them together delivered Isabella's daughter under Battista's direction, the barber making the incision and sewing it up afterward, and the midwife receiving the child.

Although the four witnesses played different roles in Camilla's birth, their declarations were strongly in agreement with one another. All were deposed at the request of Isabella's husband Marcantonio $<$ em $>$ they were in this sense "his" witnesses $<$ em $>$ and their testimony aimed to establish that Isabella's daughter had been born fully formed and alive, in order to buttress his claim on her property. Under the circumstances, it is no surprise that their accounts echoed one another verbally as well as in their content: this was a common feature of legal testimony, reflecting both the fact that witnesses were asked to testify to a standard set of points (the "headings of the accusation") and contemporary opinion regarding what made an account credible. As Daniel Lord Smail has argued, "Homogeneity was valued as an aesthetic of truth: a claim simply seemed more truthful to contemporary observers if opinions regarding it were relatively uniform, and if elements of subsequent depositions echoed each other in their syntax and vocabulary." ${ }^{18}$

All four of Marcantonio's witnesses reiterated the central points of his case, in virtually identical words: although Isabella was dead when her uterus was opened, the child extracted 
from it was alive ( $\underline{\text { viva }})<$ em $>$ as shown by the fact that it moved its hands and feet $<$ em $>$ and

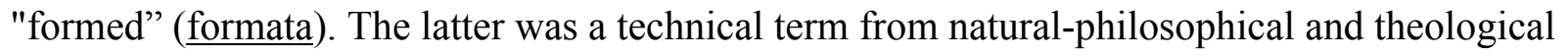
discourse; fetuses were not considered human until their bodies had achieved human form, which happened somewhere between thirty and ninety days after conception, depending on their sex (female fetuses, being wetter by nature, took longer to solidify than male ones). At this point, God infused them with a human soul. This is the reason for the witnesses' testimony that Isabella's daughter had "all its members separate and distinct," or, in the words of the maidservant Franceschina, "it had suitably shaped hands and fingers that were appropriately long, defined, and separated." The humanity of the fetus was confirmed by the fact that the child was baptized by the priest present at Isabella's deathbed, as all the witnesses emphasized; it was strictly forbidden to baptize stillborn children or fetuses that had not yet achieved human form. ${ }^{19}$

Despite their unanimity on the issues key to Marcantonio's case, the witnesses' depositions reflect the different roles they played in the affair. Battista de Crollis, the surgeon, spoke primarily to medical matters: the nature of Isabella's illness, his prescription of a medicated bandage according to a recipe in a well-known antidotary, his several visits to her bedside, and his presence at her death. It was he who notified her husband that she had died. Although he refused to open Isabella's body himself, it is clear that he was familiar with the operation. He made sure that she was dead by holding a piece of cotton to her nostrils; he propped open her mouth so that her fetus might breathe, in accordance with the procedure described by Guy de Chauliac; and he instructed the barber on how to open Isabella's corpse and sew it up again. The barber Stefano de Fango confirmed Battista's account of the surgical procedure. In contrast, the priest Bernardino de Maximinis, focused on the religious aspect of the 
proceedings: he had confessed Isabella several days before her death, when she could still speak, and he spoke the final prayer, the Commendatio animae, over her as she died. He left the room during the surgery, together with the other women, but he returned immediately afterward to baptize the child.

The fourth witness, Isabella's maidservant Franceschina, described the events as they appeared to the women who cared for Isabella during her last illness and watched with her on her deathbed, unlike the priest and the medical men, who came and went. Franceschina's greater involvement in the events surrounding Isabella's death is clear from her mastery of the details. She was the only one of the four witnesses who remembered the exact date of the events in question (15 September) and the day of the week (Tuesday); she noted that Isabella died in her bedroom, on the second floor of the house of her brother-in-law Francesco de Cusano, with whom she and her husband, Marcantonio de Cusano, apparently lived. Franceschina was also the only one who could identify everyone involved in the proceedings, including all the women: herself; the midwife Elena; Isabella's sister-in-law Caterina, wife of Francesco de Cusano; Caterina's servant Astasia; Ambruogina, the servant of Isabella's paternal uncle; and the wife of one Giovanni Antonio Lexone. In particular, Franceschina confirmed that the decision to extract the fetus was taken by the women; it was they who determined that the fetus was alive and asked Battista to perform the operation. She waited with them outside the room while the extraction was performed $<\mathrm{em}>$ they may have been reluctant to witness the procedure, or the medical men may have wished to operate in calm $<$ em $>$ and it was she who recounted the words with which someone called for the priest: "Hey, hey, come quickly to help the soul of this child" ("Ola, ola, corriti presto per aiutar l'anima di questa putta"). 
As I have emphasized, all of the witnesses were associated with Isabella's husband, as opposed to her paternal uncle Nicola della Volpe, who was probably the plaintiff in the case. The voices of Nicola's servant Ambruogina, his natural son Francesco, and the midwife, all present at the events, are conspicuously lacking, and it is quite possible that they would have testified on Nicola's behalf that Isabella had not delivered a living heir. And they might have had good reason to do so. The surgeon testified that the barber who performed the operation arrived roughly half an hour after he was called. This meant that the child was extracted at least forty minutes after Isabella's death, even if one allows only ten minutes for the events separating the death and the decision to call the barber: the women's lamentations, their determination that the fetus was moving, their search for the surgeon (then elsewhere in the house), their request that he perform the procedure, his refusal, and his suggestion that a barber be called. Given that Isabella had been critically ill for at least three or four days before her death, and that time is of the essence in postmortem caesareans $<\mathrm{em}>$ one recent discussion recommends that the procedure be initiated "within four minutes of maternal cardiac arrest" ${ }^{20}<\mathrm{em}>$ it is likely that her daughter was not quite as lively as Marcantonio's witnesses described. In particular, the midwife, conspicuously absent among Marcantonio's witnesses, might have told another story. It may be further grounds for suspicion that all three of the witnesses who referred to the daughter's ensuing death (the surgeon, the barber, and the maidservant) denied having been present at the time.

Given the circumstances, one of the most puzzling aspects of the case is the decision of the surgeon, Battista de Crollis, to delay opening Isabella's corpse, against the interests of both her fetus and her husband. His only explanation was that he "did not have it in him [non habere 
animum]." Whether he was moved by respect, personal affection, inexperience, desire to avoid an operation with which he was familiar only in theory, fear of taking the blame for delivering a stillborn baby, or conflicted loyalty to both the della Volpe and the Cusano families, may never be entirely clear. Nor do we know the outcome of the case prepared by Isabella's husband $<$ em $>$ or even if it progressed to an actual trial. Whatever actually happened in the upper room of Marcantonio's house, however, these declarations shed new light on several important aspects of the early history of the caesarean procedure: the fact that the operation was well known and widely accepted, the central role played by women in deciding to call a surgeon, and the well-established division of labor between doctors and midwives in Italian obstetrical practice. Above all, it shows that the operation had legal and financial as well as religious implications, especially in the case of a firstborn child. 
<COMP: see attached for style>

$<$ A $>$ Appendix

$<$ B $>$ I. Transcription ${ }^{21}$

$\left[1^{\mathrm{r}}\right]$ Yhesus Maria

Protocollum instrumentorum receptorum per me Gasparem de Linore de Badaloco notarium publicum manualiter et signo tabellionatu subsignatum improtocollatorum de anno millesimo quingentesimo quadragesimo sexto et septimo.

$<11$ s $>$

Propallatio pro spectabili domino Marco Antonio de Cusano facta per dominum Baptistam de Crollis chirurgicum Vercellarum.

$<1$ ls $>$

Anno domini currente millesimo quingentesimo quadragesimo sexto die prima mensis aprilis. Universis sit manifestum quod dominus Baptista de Crollis civis et chirurgicus Vercellarum, vigore litterarum monitorialium instante magnifico domino Marco Antonio de Cusano emanatarum a reverendo domino vicario curie episcopalis Vercellensis sub die herina ultima martii proxime fluxi sibi ostensarum et in exonus sue conscientie, cum iuramento prestito in manibus mey notarii subsignati, propallavit se de constitutis in capitulis monitorialibus in pede dictarum litterarum descriptis per eum lectis et intellectis scire $\left[1^{\mathrm{v}}\right]$ et verum esse: Quod dominus 
propallans ipse ex longeva benivolentia et amicitia domini Nicole della Vulpe et suorum ac domini de Cusano debitam visitationem domine quondam Ysabelle in dictis capitulis monitorialibus rellate durante sua ultima infirmatate qua decessit de anno proxime fluxo et mense septembris, si bene meminit, adhibuit. Et cum amisisset loquellam tribus seu quatuor diebus precedentibus eius mortem ex opulatione cerebri, ut omnes fisici arbitrabantur, iuxta

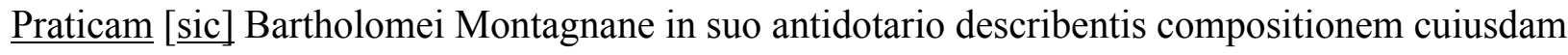
ciroti, ex cuius applicatione super comissura coronali quamplurimos a tali mala dispositione curasse. Ordinavit tale cirotum quod super comissura coronali dicte quondam domine Ysabelle in mane diey antecedentis eius mortem posuit. Et in sero reperit illud talem operationem fecisse, quod omnes de eius domo arbitrabantur precedente tamen divino auxilio eandem consequi sanitatem debere. In mane vero diey tunc sequtum et sic die mortis eiusdem domine Ysabelle, reperit eandem dictum cirotum a loco suo abstulisse seu illud lapsum, quod reformavit.

Et cum circa horam decimam octavam eius iudicio accessisset visum an illud prestetisset aliquod adiuvamentum ipse domine Ysabelle, eandem reperit laborare in extremis, $\left[2^{\mathrm{r}}\right]$ et venerandus parrochianus Sancte Agnetis tunc comendabat animam suam, quod videns intellectoque spectabilem dominum Marcum Antonium suum maritum adesse in quadam camera ibi propinqua, eum visitatum adivit et quem tunc visitavit, qua visitatione sequta illinc recessit, et cum fuit super hostio dicte camere obviam fecit cuidam Francisco, filio naturali prefati domini Nicole dela Vulpe patrui eiusdem quondam domine Ysabelle, ploranti et dicenti eandem dominam Ysabella expirasse, quod audiens illuc accessit et vidit ipsam mortuam. Domina vero sua cugnata, Astasia ancilla domini Francisci de Cusano, quedam alia ancilla prefati domini Nicole dela Vulpe, et nonnulle alie mulieres ibi existentes flebant et tristabantur de morte 
eiusdem domine Ysabelle. Deinde dixerunt sese tetigisse locum fetus predicte domine Ysabelle et percepisse per tactum manus dictum fetum vivere et se movere, et propterea deberi peragere taliter quod extraheretur ipse fetus ex utero iam dicte domine Ysabella postquam erat mortua, ut baptizaretur ad salvationem animam eiusdem. Et tunc idem dominus propallans eiis dixit ob reverentiam predicte domine non habere animum incidere $\left[2^{\mathrm{v}}\right]$ cadaver eiusdem causa extrahendi dictum fetum viventem, tamen quod quererent unum barbitonsorem et eydem modum daret incidendi et extrahendi ut supra. Et posuit bombacem ad nares iam dicte domine Ysabelle ut perciperet an viveret vel ne. Et percipiens ipsam totaliter mortuam posuit canulos ligneos inter dentes ut os suum aperiretur, ne fetus ipse causa suffocationis defficeret.

Postmodum illinc ad mediam horam vel circa suo iudicio, supervenit magister Stephanus de Fango habitator et barberius Vercellarum, qui via ipsius domini propallantis et eo ac quadam obstetrice cuius nomen et cognomen ignorat presentibus, processit ad incisionem uteri predicti. Et ex eo fuit extracta una filia viva et se movens pedibus et manibus, optime proportionata cum omnibus suis membris distinctis et divisis, et quam ipsa obstetrix in suis manibus tunc accepit. Ipse vero dominus propallans vocavit dictum curatum, sic quod omnes mulieres que exiverant ipsam cameram et dictus dominus curatus illuc accesserint. Et in quarum et ipsius domini propallantis presentia ipsa filia per dictum dominum $\left[3^{\mathrm{r}}\right]$ curatum fuit baptizata et impositum nomen Camilla. Et dictus magister Stephanus barberius fuit patrinus eiusdem. Quo facto ipse dominus propallans operam dedit in suere faciendo per ipsum barberium dictam incisionem cadaveris. Et opere perfecto illinc recessit, dimissis omnibus suprascriptis, et que filia ut postea percepit decessit illinc ad paucum tempus.

Et dicit quod superius per eum propallata fuerunt et sunt vera, causam scientie reddens 
quia scit, vidit, egit, et dici audivit ea que et prout supra respective propallavit. De quibus requisivit fieri testimoniales per me notarium subsignatum, datas et actas Vercellis in scriptorio infranominati nobilis domini Ioannis Antonii de Advocatis Bene, presentibus eodem domino Ioanne Antonio et egregio Ioanne Antonio de Bruxis de Crepacorio scriba ipsius domini Ioannis Antonii de Advocatis, anno et die premissis.

$<1$ ls $>$

Alia propallatio pro eodem spectabili domino Marco Antonio de Cusano facta per venerandum presbiterum Bernardinum de Maximinis de Candello.

$<1$ ls $>$

Anno domini currente millesimo quingentesimo quadragesimo sexto die secunda mensis aprilis. Universis sit $\left[3^{\mathrm{v}}\right]$ manifestum quod venerandus dominus presbiter Bernardinus de Maximiniis [sic] de Candelo curatus Sancte Agnetis Vercellarum, vigore litterarum monitorialium instante spectabili artium et medicine doctore domino Marco Antonio de Cusano emanatarum a reverendo domino vicario curie episcopalis Vercellarum sub die ultima mensis marcii proxime fluxi sibi ostensarum, cum iuramento prestito in manibus mey notarii subsignati et in exonus sue conscientie, propallavit se de constitutis in capitulis monitorialibus sibi lectis et per eum intellectis scire et verum esse: Quod de anno proxime fluxo et si bene meminit de mense septembris propallans ipse bis audivit peccata quondam domine Ysabelle in ipsis capitulis nominate tunc infirmantis quadam infirmitate qua postea decessit in camera sua cubiculari existente desuper portam domus habitationis eiusdem, ubi die sui obitus animam eiusdem cum laboraret in extremis comendavit. Qua comendatione perfecta ut legendo passionem domini nostri Iesu Cristi emisit spiritum. Domina vero cugnata sua et alie mulieres ibi existentes 
ceperunt flere et tristari de morte predicta. Et tetigerunt locum fetus eiusdem et dixerunt illum $\left[4^{\mathrm{r}}\right]$ vivere et se movere, et subito supervenit dominus Baptista de Cossato chirurgicus Vercellarum, cui premissa notifficarunt querentes postquam ipsa domina Ysabella erat mortua extractionem dicti fetus pro salvatione anime eiusdem, qui tunc eiis respondidit [?] et dixit non habere animum ad ita peragendum, sed vocarent aliquem barbitonsorem et ey daret modum extrahendi fetum ipsum. Deinde supervenerunt magister Stephanus de Fango barberius Vercellarum et quedam obstetrix cuius nomen nescit. Et tunc propallans ipse se retraxit extra ipsam cameram ubi fuit sibi dictum ut prestolaretur [?] extractionem dicti fetus causa eum baptizandi. Predicti vero dominus Baptista chirurgicus et magister Stephanus barberius processerunt ad incisionem uteri eiusdem domine Ysabelle, et ex eo fuit extracta una filia. Et subito ipse dominus propallans vocatus per astantes ad baptizandum ipsam filiam quam vivam et se moventem pedibus et manibus ut solent facere filii quando nascuntur vidit et baptizavit in presentia quorum supra, et dictus magister Stephanus barberius fuit patrinus eiusdem, $\left[4^{\mathrm{V}}\right]$ et imposuit ey nomen Camilla, et erat prout et vidit bene formata ac habebat omnia membra separata et distincta.

Et dicit quod superius per eum propallata fuerunt et sunt vera, causam assignans quia scit, vidit, baptizavit, nomen inposuit, egitque, et dici audivit ea que ut prout superius respective propallavit, de quibus requisivit fieri testimoniales per me notarium subsignatum, datas et actas Vercellis in camera quadam existente desuper dictam ecclesiam Sancte Agnetis presentibus Nicola de Camagneto quondam Nicolay et Francisco de Albis quondam Eusebii civibus Vercellarum anno et die premissis.

$<1$ ls $>$ 
Alia propallatio pro eodem spectabili domino Marco Antonio de Cusano facta per magistrum

Stephanum de Fango barberium Vercellarum.

$<1$ ls $>$

Anno domini currente millesimo quingentesimo quadragesimo sexto die quarta mensis aprilis. Universis sit manifestum quod magister Stephanus de Fango de Bugella barberius et habitator Vercellarum, vigore litterarum monitorialium instante spectabili artium et medicine doctore domino $\left[5^{\mathrm{r}}\right]$ Marco Antonio de Cusano emanatarum a reverendo domino vicario curie episcopalis Vercellarum sub die ultima mensis martii proxime decursi sibi ostensarum, cum iuramento prestito in manibus mei notarii subsignati et in exonus sue conscientie, propallavit se de constitutis in capitulis monitorialibus sibi lectis et per eum intellectis scire et verum esse: Quod de anno proxime fluxo et si bene meminit de mense septembris, propallans ipse presentibus domino magistero Baptista chirurgica [ $\underline{\mathrm{sic}}]$ et Helena obstetrice die obitus domine Ysabelle uxoris quondam ipsius domini Marci Antonii de Cusano, et ea mortua, incisit locum fetus eiusdem. Et ex eo loco fuit extracta una filia viva et optime formata, omnibus membris distinctis et separatis prout vidit ipse propallans. Indeque et in manibus dicte obstetricis fuit per venerandum dominum curatum Sancte Angetis baptizata et impositum nomen Camille, et ey propallans ipse fuit patrinus. Quibus gestis presente et vidente dicto domino Baptista chirurgico suit incisionem predictam, deinde recessit. Et $\left[5^{\mathrm{V}}\right]$ ipsa filia ut postea percepit decesse illinc ad paucum tempus seu paucam horam.

Et dicit quod superius per eum propallata fuerunt et sunt vera, causam sue scientie reddens quia scit, vidit, egit, incisit, suitque, et dici audivit ea que et prout superius respective propallavit, de quibus requisivit fieri testimoniales per me notarium subsignatum presentibus 
nobili domino Ioanne Antonio de Advocatis Bene cive et notario publico Vercellarum et Bernardo Barbonaia de Stroppiana, datas et actas Vercellis in scriptorio prefati domini Ioannis Antonii presentibus quibus supra anno et die premissis.

$<1$ ls $>$

Alia propallatio pro eodem spectabili domino Marco Antonio de Cusano facta per Franceschinam relictus Bartholomei de Novaria habitatricem Vercellarum.

$<1$ ls $>$

Anno domini currente millesimo quingentesimo quadragesimo sexto die quinta mensis aprilis. Universis sit manifestum quod Franceschina relictus Bartholomey de Novaria olim habitatoris et textoris tellarum Vercellarum, vigore litterarum monitorialium instante spectabili artium et $\left[6^{\mathrm{r}}\right]$ medicine doctore domino Marco Antonio de Cusano emanatarum a reverendo vicario curie episcopalis Vercellarum sub die ultima mensis marcii proxime fluxi sibi ostensarum, cum iuramento prestito in manibus mey notarii subsignati et in exonus sue conscientie, propallavit se de constitutis in capitulis monitorialibus in pede ipsarum litterarum descriptis sibi lectis et per eum intellectis scire et verum esse: Quod propallans ipsa uti inquilina spectabilis domini Francisci de Cusano de anno proxime decurso durante infirmitatem quondam domine Ysabelle in dictis capitulis nominate stetit ad servitutem eiusdem et que decessit in eius camera cubiculari existente desuper portam domus eiusdem domini Francisci de Cusano quadam die martis quindecima septembris proximi decursi et circa horam octave [sic] suo iudicio. Et ipsi morti interfuit et pariter interfuerunt venerandus curatus Sancte Agnetis, domina cugnata ipsius quondam domine Ysabelle, domina uxor domini Ioannis Antonii Lexone, Ambroxina ancilla domini Nicole dela Vulpe patrui eiusdem domine Ysabelle, Astasia pedisequa [6 $\left.6^{\mathrm{v}}\right]$ spectabilis 
domine Catherine de Cusano. Que omnes sequta ipsa morte tetigerunt ventrem cadaveris dicte domine Ysabelle et comprehendiderunt per tactum manus earundem fetus quem ipsa domina Ysabella habebat in ventre vivere et se movere. Et exinde dixerunt deberi peragere quod extrahereter de utero eiusdem domine Ysabella dictus fetus ut sua anima salvaretur, attento maxime quod dicta domina Ysabella erat mortua presente domino magistro Baptista chirurgico.

Deinde supervenerunt magister Stephanus barberius et Helena obstetrix uxor magistri Petri sartoris de Sancta Agata, habitatoris Vercellarum. Et tunc ipse mulieres curatusque et ipsa propallans se retraxerunt extra ipsam cameram. Et ipsi dominus Baptista chirurgicus et magister Stephanus barberius presente dicta obstetrice processerunt ad incisionem dicti cadaveris scilicet loci predicti fetus. Et ex ipso loco extraxerunt unam filiam vivam, et subito fuit dictum fortiter, "Ola, ola, corriti presto per aiutar l'anima di questa putta," quod audientes ipse mulieres et ipsa propallans illuc cucurrerunt $\left[7^{\mathrm{r}}\right]$ et viderunt, prout vidit ipsa propallans, ipsam filiam vivam et bene formatam se moventem tibiis et manibus ut solent facere creature quando nascuntur. Et vidit eandem etiam habere manus competenter et satis longas, et digitos earumdem distinctos et separatos. Et dictus dominus curatus in presentia quorum supra et ipsius propallantis eam baptizavit et fuit ey impositum nomen Camilla. Et que filia ex inde parum vixit ut ex post intellexit.

Et dicit quod superius per eam propallata fuerunt et sunt vera, causam scientie reddens per ea que predixit respective loquendo, de quibus requisivit fieri testimoniales per me notarium subsignatum, actas et datas Vercellis in scriptorio nobilis domini Ioannis Antonii de Advocatis Bene civis et notarii publici Vercellarum anno et die premissis. 
$<$ B $>$ II. Translation

$\left[1^{\mathrm{r}}\right]$ Jesus Mary

Notebook of legal instruments received and recorded in the years 1546 and 1547 by me Gaspare de Linore of Balocco, public notary, undersigned both by hand and with my notarial sign. $<1$ 1s $>$

Deposition on behalf of the eminent signor ${ }^{22}$ Marcantonio de Cusano, made by signor Battista de' Crollis, surgeon of Vercelli.

$<1$ ls $>$

On the first day of April in the present year of our Lord 1546. Let it be known to all that signor Battista de Crollis, citizen and surgeon of Vercelli, at the instance of the magnificent signor Marcantonio de Cusano, by virtue of the accusatory document [litterarum monitorialium] issued by the reverend signor vicar of the episcopal court of Vercelli on the last day of March [and] shown to him, and in order to discharge his conscience, having sworn in the hands of me, the undersigned notary, has declared regarding the matters described in the headings of the accusation [constitutis in capitulis monitorialibus] written at the foot of the said document and read and understood by him, that he knows $\left[1^{\mathrm{v}}\right]$ and it is true that: The signor witness [propallans; i.e., Battista], moved by his long relationship and friendship with signor Nicola della Volpe and his family and with signor [Marcantonio] de Cusano, duly visited the late signora Isabella, who is referred to in the said headings of the accusation, during her last illness, of which 
she died last year in the month of September, if he recalls correctly. And since, in the judgment of all of her physicians, she had lost the power of speech three or four days before her death as a result of an obstruction of the brain, he ordered a plaster [cirotum], the composition of which is described in the antidotary of the Practica of Bartolomeo of Montagnana, ${ }^{23}$ and which has been used to treat many people for this kind of illness. He placed this on the coronal commissure of the said signora Isabella on the morning of the day before she died. And in the evening he found that it had worked so well that everyone in the house believed that, with divine aid, she would regain her health. On the morning of the next day $<$ em $>$ the day of signora Isabella's death $<$ em $>$ he found that she had removed the plaster or that it had fallen off, so he reshaped it.

And when he returned at about midday ${ }^{24}$ (in his estimation), to see whether it had been of some help to the signora Isabella, he found her in her death throes; $\left[2^{\mathrm{r}}\right]$ the Reverend parish priest of Sant'Agnese then commended her soul to God. Seeing this, and knowing that her husband, the eminent signor Marcantonio, was in a nearby room, he went to see him, and he saw him, and following this visit he left the room. And when he was outside the door of the room, he encountered a certain Francesco, the natural son of signor Nicola della Volpe, signora Isabella's paternal uncle, who was lamenting and saying that signora Isabella had died. When he heard this he went and found her dead. Signora Isabella's sister-in-law [Caterina de Cusano]; Astasia, servant of signor Francesco de Cusano [Caterina's husband and Isabella's brother-in-law]; a servant of the aforesaid signor Nicola della Volpe; and some other women were there crying and lamenting the death of signora Isabella. Then they said that they had touched the place of the fetus of signora Isabella and had perceived by the touch of their hands that the fetus lived and moved, and that therefore measures should be taken to extract the fetus from the uterus of 
signora Isabella after she was dead, so that it might be baptized to save its soul. And then the same signor [Battista] said to them that he did not have it in him cut open $\left[2^{\mathrm{v}}\right]$ her corpse to extract the living fetus, on account of his respect for the said signora Isabella, but that they should call a barber, and he would tell the barber how to do the cutting and extracting described above. And he placed a piece of cotton to signora Isabella's nostrils to see if she was alive or not. And seeing that she was completely dead, he placed small pieces of wood between her teeth to hold her mouth open, so that the fetus would not die of suffocation. ${ }^{25}$

About a half hour later (by his estimation), master Stefano de Fango, inhabitant and barber of Vercelli, arrived, and with the help of signor [Battista], and in his presence and that of a midwife whose name and family name [signor Battista] did not know, [master Stefano] proceeded to cut open the uterus, and he extracted from it a living female child, who moved her feet and hands and was well proportioned, with all her members distinct and divided, and whom the midwife received in her hands. Signor [Battista] called the priest, so that all the women, who had left the room, came back, together with the signor priest, and in their presence and that of signor [Battista], the child was baptized by the signor $\left[3^{\mathrm{r}}\right]$ priest and named Camilla. And the said master Stefano, barber, was the godfather. When this was done, signor [Battista] had the barber sew up the incision of her corpse. He then left, having sent all the others away, and he heard later that the child died shortly afterward.

And he says that the things that he has declared above were and are true, giving as the cause of his knowledge that he knows, saw, acted, and heard respectively the things that he has declared above. He asked that I, the undersigned notary, draw up this declaration [testimoniales] given and enacted in Vercelli, in the office of the noble signor Giovanni Antonio Avogadro di 
Benna, in the presence of the same signor Giovanni Antonio and the distinguished Giovanni Antonio de Bruxis of Crevacuore, the scribe of signor Giovanni Antonio Avogadro, on the aforesaid day and year.

$<1$ ls $>$

Another declaration on behalf of the eminent signor Marcantonio de Cusano, made by the reverend priest Bernardino de Maximinis of Candelo.

$<1 \mathrm{ls}>$

On the second day of April in the present year of our Lord 1546. Let it be known to all $\left[3^{\mathrm{v}}\right]$ that the reverend signor priest Bernardino de Maximinis of Candelo, priest of Sant'Agnese of Vercelli, at the instance of the eminent signor Marcantonio de Cusano, doctor of arts and medicine, by virtue of the accusatory document issued by the reverend signor vicar of the episcopal court of Vercelli on the last day of March [and] shown to him, having sworn in the hands of me, the undersigned notary, and in order to discharge his conscience, has declared concerning the matters described in the headings of the accusation written at the foot of the said document and read to and understood by him, that he knows and it is true that: Last year $<\mathrm{em}>$ and in September, if he remembers correctly $<\mathrm{em}>$ he twice heard the sins of the signora Isabella named in these headings, who was then sick with the illness of which she later died, in her bedroom above the door of her house, where on the day of her death, while she was in her death throes, he commended her soul to God. After the prayer of commendation, while he was reading the passion of our Lord Jesus Christ, she gave up her spirit. Her sister-in-law [Caterina de Cusano] and the other women present began to cry and lament her death. And they touched the place of her fetus and said that it $\left[4^{\mathrm{r}}\right]$ lived and moved. Just then signor Battista of 
Cossato, surgeon of Vercelli, arrived; they told him what had happened and asked him to extract the fetus in order to save its soul after the death of signora Isabella. He answered and said he did not have it in him to do so, but that they should call a barber, and he would tell him how to extract the fetus. Then master Stefano de Fango, barber of Vercelli, arrived, together with a midwife whose name [signor Bernardino] does not know. And then [signor Bernardino] withdrew from the room, where he was told that [the fetus would be extracted?] in order to baptize it. The aforementioned surgeon signor Battista and barber master Stefano proceeded to cut open the uterus of signora Isabella, and a daughter was extracted from it. And immediately signor [Bernardino] was called by those present to baptize the child, which he saw moving her feet and hands as children usually do when they are born. And he baptized her in the presence of those named above; master Stefano the barber was her godfather $\left[4^{\mathrm{v}}\right]$, and she was named Camilla, and as far as he could see, she was well formed and had all her members separate and distinct.

And he says that the things that he has declared above were and are true, giving as the cause of his knowledge that he knows, saw, baptized, named, acted, and heard respectively the things that he has declared above. He asked that I, the undersigned notary, draw up this deposition, given and enacted in Vercelli, in the room above the church of Sant'Agnese, in the presence of Nicola, son of the late Nicola of Camagneto, and Francesco, son of the late Eusebio de Albis, citizens of Vercelli, on the aforesaid day and year.

$<1$ ls $>$

Another declaration on behalf of the eminent signor Marcantonio de Cusano, made by master Stefano de Fango, barber of Vercelli. 
$<1$ ls $>$

On the fourth day of April in the present year of our Lord 1546. Let it be known to all that master Stefano de Fango of Biella, barber and resident of Vercelli, at the instance of the eminent signor $\left[5^{\mathrm{r}}\right]$ Marcantonio de Cusano, doctor of arts and medicine, by virtue of the accusatory document issued by the reverend signor vicar of the episcopal court of Vercelli on the last day of March [and] shown to him, having sworn in the hands of me, the undersigned notary, and in order to discharge his conscience, has declared regarding the matters described in the headings of the accusation written at the foot of the said document and read to and understood by him, that he knows and it is true that: In September of last year, if he remembers correctly, on the day of the death of signora Isabella, late wife of signor Marcantonio de Cusano $<$ em $>$ after she was dead $<$ em $>$ he cut open the place of the fetus in the presence of signor master Battista, surgeon, and Elena, midwife. And from that place a daughter was extracted, alive and well formed, with all her members distinct and separate as far as [master Stefano] could see, and as a result she was baptized in the hands of the midwife by the venerable signor priest of Sant'Agnese and named Camilla, and [master Stefano] was the godfather. Once this was done, and in the sight of the said signor Battista, surgeon, he sewed up the incision and left. And $\left[5^{\mathrm{v}}\right]$ as he later learned, the child died a short while later.

And he says that the things that he has declared above were and are true, giving as the cause of his knowledge that he knows, saw, acted, cut, sewed, and heard respectively the things that he has declared above. He asked that I, the undersigned notary, draw up this deposition in the presence of the noble signor Giovanni Antonio Avogadro di Benna, citizen and public notary of Vercelli, and Bernardo Barbonaia of Stroppiana, given and enacted in Vercelli in the office of 
the said signor Giovanni Antonio on the aforesaid day and year.

$<1$ ls $>$

Another declaration on behalf of the eminent signor Marcantonio de Cusano, made by

Franceschina, daughter of the late Bartolomeo of Novara, resident of Vercelli.

$<1 \mathrm{ls}>$

On the fifth day of April in the present year of our Lord 1546. Let it be known to all that Franceschina, daughter of the late Bartolomeo of Novara, weaver, who used to live in Vercelli, at the instance of the eminent signor $\left[6^{\mathrm{r}}\right]$ Marcantonio de Cusano, doctor of arts and medicine, by virtue of the document of accusation issued by the reverend lord vicar of the episcopal court of Vercelli on the last day of March [and] shown to her, having sworn in the hands of me, the undersigned notary, and in order to discharge her conscience, has declared regarding the matters described in the headings of the accusation written at the foot of the said document and read to and understood by her, that she knows and it is true that: [Franceschina], tenant of the eminent signor Francesco de Cusano, was the servant of the late signora Isabella named in the said headings, and that [signora Isabella] died in her bedroom over the door of the house of signor Francesco de Cusano on Tuesday, the fifteenth of September last, around the hour of the octave [horam octave], in her judgment. ${ }^{26}$ And she was present at the death, together with the venerable priest of Sant'Agnese; the sister-in-law of the late signora Isabella;; the signora wife of the signor Giovanni Antonio Lexone; Ambruogina, servant of the signor Nicola della Volpe, paternal uncle of signora Isabella; [and] Astasia, servant $\left[6^{\mathrm{v}}\right]$ of the eminent signora Caterina de Cusano. Following [signora Isabella's] death, everyone touched the belly of the corpse of the said signora Isabella and understood by the touch of their hands that the fetus the signora Isabella had in her 
belly lived and moved. And consequently they said that the fetus should be extracted from the uterus of the said signora Isabella so that its soul might be saved, especially since the said signora Isabella had died in the presence of signor master Battista, surgeon.

Then arrived master Stefano, barber, and Elena, midwife and wife of master Pietro of Sant'Agata, tailor and resident of Vercelli. The women and the priest and [Franceschina] left the room. And signora Battista, surgeon, and master Stefano, barber, proceeded in the presence of the midwife to cut open the said corpse, that is to say, the place of the fetus. And from it they extracted a living daughter, and someone suddenly cried, "[in Italian] Hey, hey, come quickly to help the soul of this child." ${ }^{27}$ Hearing this the women and [Franceschina] ran $\left[7^{\sharp r}\right]$ and saw, as [Franceschina] saw, that the child was alive and well formed, moving its legs and hands as babies usually do when they are born. And she saw that it had suitably and appropriately long hands, with fingers that were distinct and separated. And the said signor priest, in the presence of those named above and [Franceschina], baptized her and she was named Camilla. And the child lived only a short while, as she later learned.

And she says that the things that she has declared above were and are true, giving as the cause of her knowledge those things that she has said above. She asked that I, the undersigned notary, draw up this deposition, given and enacted in Vercelli in the office of the noble Lord Giovanni Antonio Avogadro di Benna, citizen and notary public of Vercelli, on the aforesaid day and year.

$<$ dingbat + rules $>$ $<$ ext $>$ 
$<\mathrm{sc}>$ Katharine Park $<$ end $\mathrm{sc}>$ is Samuel Zemurray, Jr. and Doris Zemurray Stone Radcliffe Professor of the History of Science at Harvard University, where she teaches and writes on the history of science and medicine in medieval and Renaissance Europe, as well as the history of gender, sexuality, and the body. Her most recent book, Secrets of Women: Gender, Generation, and the Origins of Human Dissection (Zone Books, 2006), won the 2007 Margaret W. Rossiter History of Women in Science Prize of the History of Science Society. She is currently working on the history of scientific observation in the Middle Ages. Her address is: Department of the History of Science, Science Center 371, Harvard University, Cambridge MA 02138 (e-mail: park28@fas.harvard.edu). 
$<$ NOTES $>$

$<$ unnumbered note>

My thanks to Giovanna Benadusi, Monica Green, and Daniel Lord Smail for help in translating and interpreting the document; to Graziana Bolengo of the Archivio di Stato di Biella, for making it available to me for study; and to Patrizia Carpo of the Archivio Storico Comunale di Vercelli, for help in finding other relevant archival materials. All translations are my own.

1. Archivio di Stato di Biella, Archivio del Centro Studi Cavaliere Pietro Torrione, Raccolta, mazzo 11, fasc. 11 (notarial register of Gaspare de Linore, 1546<en $>48$ ), fols. $1^{\mathrm{r}}<\mathrm{en}>7^{\mathrm{r}}$. There is a blurry facsimile of these folios in E. Tardito, "Tagli cesarei di altri tempi," Minerva medica, 24 November 1968, 94, Suppl.: 5079<en>5106, which contains background information concerning some of the principals involved in the case, as well as a partial transcription and partial Italian translation. For Vercelli's population in this period, see Sabrina Balzaretti, Nobili e borghesi a Vercelli alla fine dell'antico regime (Vercelli: Società Storica Vercellese, 2005), p. 29.

2. The agreement regarding Isabella's dowry (25 September 1544$)$ and the deathbed will of her father Agostino del fu Uberto della Volpe (6 August 1542) appear in the notarial records of Ardizzone de Cagnolis; see Archivio Storico Comunale di Vercelli, Atti notarili, not.

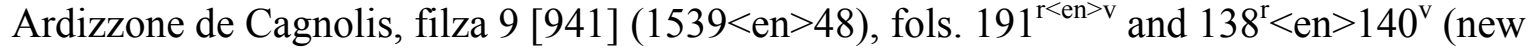
numeration). Isabella was to receive the 800 scudi from her father's will on her marriage.

3. Isabella's dowry agreement states specifically that, in conformity with the statutes of Vercelli, the dowry would revert to her family if she died without children (fol. 191 ${ }^{\mathrm{v}}$ ). Thomas Kuehn has suggested (personal communication via Daniel Lord Smail) <AU: personal communication? $>$ that the declarations may have been gathered so as to prepare a consilium pro parte, which could be wielded beforehand to dissuade a lawsuit. On practices and conflicts concerning women's property in this region, see Sandra Cavallo, Charity and Power in Early Modern Italy: Benefactors and Their Motives in Turin, $1541<$ en $>1789$ (Cambridge: Cambridge University Press, 1995), pp. 171<en $>77$.

4. At least two other legal cases, in fourteenth-century Denmark and Marseille, turned on this issue. For the former, adjudicated in 1360 by the king of Sweden, see Dyre Trolle, The History of Caesarean Section (Copenhagen: Reitzel, 1982), p. 22. My thanks to Monica Green for this reference; additional references appear in O. T. Hult, "Ur Kejsarsnittets äldre historia," Lychnos: Annual of the Swedish History of Science Society, 1939: 243<en>61, at p. 243. The king determined that the child had been born alive and fully formed, and thus decided in favor of the father. I know of the Marseille case from Daniel Lord Smail (personal communication); there, the husband sued his mother-in-law in 1331 for refusing to have a caesarean section performed, thereby depriving him of an heir and his wife's property.

5. Montserrat Cabré, trans., "Public Record of the Labour of Isabel de la Cavalleria. January 10, 1490. Zaragoza," The Online Reference Book for Medieval Studies, http://www.the-orb.net/birthrecord.html (accessed 13 January 2006); Monica Green and Daniel Lord Smail, "The Trial of Floreta d'Ays (1403): Jews, Christians, and Obstetrics in Later Medieval Marseille," J. Mediev. Hist., forthcoming 2008: 34.

6. General early histories of the procedure include Daniel Schäfer, Geburt aus dem Tod: Der Kaiserschnitt an Verstorbenen in der abendländischen Kultur (Hürtgenwald: Pressler, 1999), who discusses the operation performed on Isabella on pp. $55<\mathrm{en}>60$; Schäfer, "Embryulkie 
zwischen Mythos, Recht und Medizin: Zur Überlieferungsgeschichte von Sectio in mortua und Embryotomie in Spätantike und Mittelalter," Medizinhistorisches J., 1996, 31: 275<en>97; Nadia Maria Filippini, La nascita straordinaria: Tra madre e figlio, la rivoluzione del taglio cesareo (sec. XVIII<en>XIX) (Milan: Angeli, 1995); Trolle, History of Caesarean Section (n. 4). I do not recommend Renate Blumenfeld-Kosinski's untrustworthy Not of Woman Born: Representations of Caesarean Birth in Medieval and Renaissance Culture (Ithaca: Cornell University Press, 1990). On the currency of the operation in Renaissance Italy, see Katharine Park, Secrets of Women: Gender, Generation, and the Origins of Human Dissection (New York: Zone Books, 2006), pp. 17, 64<en>65, 134<en >35, 150<en>58, 239<en >48.

7. Pliny, Natural History, 7.9.47. On the iconographical tradition of this scene, see LouisFernand Flutre, "La naissance de César," Aesculape, 1934, 24: 244<en>50; F. v. Zglinicki, Geburt: eine Kulturgeschichte in Bildern (Braunschweig: Westermann, 1983), chap. 5; Schäfer, Geburt aus dem Tod (n. 6), pp. 51<en $>52$. The invention of the adjective "caesarean" to describe the operation was the work of the French practitioner François Rousset, in his Traittié nouveau de l'histerotomotokie; ou, enfantement césarien (Paris, 1581).

8. For some rare exceptions, when the mother was on the point of death, see Schäfer, Geburt aus dem Tod (n. 6), pp. 52<en $>54$. Rousset proposed extracting the fetus through an incision made in the uterus of a living woman in his Traittié nouveau (n. 7), and a debate ensued over this proposal; it was generally rejected as an act of pointless cruelty until the second half of the eighteenth century, when it came into occasional practice. See Filippini, La nascita straordinaria (n. 6), pp. $47<$ en $>58,159<$ en $>62$.

9. On the increasing commitment to the baptism and salvation of infants over the course of the Middle Ages, see Katharine Park, "Birth and Death," in A Cultural History of the Human Body, ed. Monica Green, vol. 2: A History of the Human Body in the Medieval Age (Oxford: Berg, forthcoming 2010) and the literature cited therein. On the problem of burying women with unbaptized fetuses in holy ground, see Ludwig Schmugge, "Im Kindbett gestorben: Ein kanonistisches Problem im Alltag des 15. Jahrhunderts," in Grundlagen des Rechts: Festschrift für Peter Landau zum 65. Geburtstag, ed. R. M. Helmholz, P. Mikat, et al. (Paderborn: Schöningh, 2000), pp. 467<en $>76$. I have found no Italian references to this doctrine, and no instances of women denied Christian burial for this reason.

10. Schäfer, Geburt aus dem Tod (n. 6), p. 45.

11. Guy de Chauliac, Inventarium, sive Chirurgia magna, 6.2.7, ed. Michael R. McVaugh, 2 vols. (Leiden: Brill, 1997), 1:389. On the Lex Regia and descriptions of the caesarean procedure in medical texts from the early fourteenth through the sixteenth centuries, see Schäfer, Geburt aus dem Tod (n. 6), pp. $21<\mathrm{en}>22,43<\mathrm{en}>51$.

12. Gaspare Nadi, Diario bolognese, ed. Corrado Ricci and A. Bacchi Della Lega (Bologna: Romagnoli Dall'Acqua, 1886), p. 52.

13. Transcribed in Jacqueline Musacchio, The Art and Ritual of Childbirth in Renaissance Italy (New Haven: Yale University Press, 1999), pp. $27<\mathrm{en}>31$.

14. Pietro d'Argellata, Chirurgia Argelate cum Albucasi, 5.19.6 (Venice, 1520), fol. $112^{\mathrm{r}}$ : "Teneatur os mulieris mortue apertum, et similiter matrix, et hoc ut aer possit ingredi et puer possit eventari. Aperiatur ergo mulier secundum longitudinem ventris cum rasorio in latere sinistro, quia pars illa est magis libera quam dextra propter epar, et digitis interpositis extrahatur fetus. Ego aliquando feci incisionem a pomo granato usque ad hos [sic] pectinis cum cautela, ne 
intestina et puer tangantur, et per istum modum extraxi puerum. Verum primus modus plus placet mihi, et per hunc modum extractus fuit Julius Cesar, ut scribitur in Gesta Romanorum." Another Bolognese case from roughly the same period is described by the famous anatomist and surgeon Jacopo Berengario of Carpi: Carpi commentaria cum amplissimis additionibus super anatomia Mundini (Bologna, 1521), fols. $211^{\mathrm{v}}<\mathrm{en}>212^{\mathrm{r}}$.

15. Schäfer, Geburt aus dem Tod (n. 6), pp. $38<$ en $>43$.

16. Park, Secrets of Women (n. 6), pp. 132<en $>40$; Monica H. Green, "Bodies, Gender, Health, Disease: Recent Work on Medieval Women's Medicine," Stud. Mediev. \& Renaiss. Hist., n.s., 2005, 1: $1<\mathrm{en}>46$, on pp. $15<\mathrm{en}>16$.

17. This well-established division of labor may account in part for the relative lack of autonomy on the part of Italian midwives relative to their fifteenth- and sixteenth-century northern European counterparts. On the role of northern midwives in caesarean operations, see Schäfer, Geburt aus dem Tod (n. 6), pp. $38<$ en $>43$.

18. Daniel Lord Smail, "Witness Programs in Medieval Marseille," in Voices from the Bench: The Narratives of Lesser Folk in Medieval Trials, ed. Michael Goodich (New York: Palgrave Macmillan, 2006), pp. 227-50, on p. 247.

19. For more regarding these matters, see Park, "Birth and Death" (n. 9).

20. V. L. Katz, D. J. Dotters, and W. Droegmeuller, "Perimortem Cesarean Delivery," Obstet. \& Gyn., 1986, 68: 571<en> 76, abstract. See also Melissa Whitten and Laurie Montgomery Irvine, "Postmortem and Perimortem Caesarean Section: What Are the Indications?" J. Roy. Soc. Med., 2000, 93: 6-9, on p. 8.

21. Notarial register of Gaspare de Linore, $1546<\mathrm{en}>48$ (n. 1), fols. $1^{\mathrm{r}}<\mathrm{en}>7^{\mathrm{r}}$; these represent the first seven folios of a forty-eight-page register. I have retained the original orthography but have silently expanded abbreviations and added punctuation for clarity. I have omitted the notary's sign and signature, which appear in the left margin of the first paragraph and at the end of the document, respectively, as well as the notarial formula accompanying each declaration that certifies that it was "rogatum et datum Nicole dela Vulpe vigore precepti ducalis mihi facti."

22. Dominus: a title of respect given to knights and gentlemen.

23. In his Antidotarium, the celebrated fifteenth-century medical writer Bartolomeo of Montagnana gave recipes for a number of bandages (cerote) to be applied to the head: Antidotarium, 3 , in Consilia Magistri Bartholomei Montagnane ... Antidotarium eiusdem ... (Lyon, 1525), fol. $461^{\mathrm{r}<\mathrm{n}>\mathrm{v}}$. The two that seem to fit the case best are two against "the descent of catarrh," which were applied to the coronal commissure after shaving the head, rubbing the scalp until it reddened, and applying leeches without scarification.

24. Literally, "the eighteenth hour"; the system of "Italian hours" was based on twentyfour hours numbered beginning at dusk.

25. This was standard medical practice in such cases; see the references in nn. 11 and 14 above.

26. Cf. the declaration of the first eyewitness, the surgeon Battista de Crollis, who placed Isabella's death at the eighteenth hour.

27. The notary transcribed this cry in Italian (where the rest of the document was in Latin), implying that it was a direct quotation. 
Figure 1. Birth of Caesar. From Suetonius, Suetonius Tranquillus [De vita duodecim caesarum], ed. Filippo Beroaldo and Marco Antonio Sabellico (Venice, 1506), fol. [1 $\left.{ }^{\mathrm{r}}\right]$. The midwife and barber or surgeon are easily identifiable. At least two of the other women appear to be servants or attendants; the one on the left holds a cloth to receive the baby. The men on the right probably represent the distraught father (second from the right) and his male friends or relatives; in reality, they are unlikely to have been present at an operation of this sort. In Isabella's case, the only people present at Camilla's delivery were the surgeon, the barber, and the midwife. Reproduced by permission of Houghton Library, Harvard University. 